\title{
The Effect of Apium Graveolens L., Levisticum Officinale and Calendula Officinalis L. on Cell Viability, Membrane Integrity, Steroidogenesis, and Intercellular Communication in Mice Leydig Cells in Vitro
}

\author{
Tomas JAMBOR ${ }^{1}$, Julius ARVAY ${ }^{2}$, Eva TVRDA ${ }^{3}$, Anton KOVACIK ${ }^{3}$, Hana GREIFOVA ${ }^{3}$, \\ Norbert LUKAC ${ }^{3}$
}

${ }^{1}$ BioFood Centre, Faculty of Biotechnology and Food Sciences, Slovak University of Agriculture in Nitra, Nitra, Slovak Republic, ${ }^{2}$ Department of Chemistry, Faculty of Biotechnology and Food Sciences, Slovak University of Agriculture in Nitra, Nitra, Slovak Republic, ${ }^{3}$ Department of Animal Physiology, Faculty of Biotechnology and Food Sciences, Slovak University of Agriculture in Nitra, Nitra, Slovak Republic

Received March 9, 2021

Accepted May 11, 2021

Epub Ahead of Print June 2, 2021

\section{Summary}

Several plants have the potential to protect essential reproductive processes such as spermatogenesis or steroidogenesis, however, effective concentrations and main mechanisms of action are still unknown. This in vitro study was aimed to assess the effects of Apium graveolens L., Levisticum officinale, and Calendula officinalis $\mathrm{L}$. extracts on the structural integrity, functional activity and gap junctional intercellular communication (GJIC) in mice Leydig cells. TM3 cells were grown in the presence of experimental extracts $(37.5,75,150$ and $300 \mu \mathrm{g} / \mathrm{ml})$ for $24 \mathrm{~h}$. For the present study, high-performance liquid chromatography analysis was used to quantify flavonoids or phenolic acids. Subsequently, Leydig cell viability was assessed by alamarBlue assay, while the cell membrane integrity was detected by 5-carboxyfluorescein diacetate-acetoxymethyl ester. The level of steroid hormones production was determined by enzyme-linked immunosorbent assay. Additionally, GJIC was assessed by scalpel loading/dye transfer assay. According to our results, Apium graveolens L. significantly increased the viability and cell membrane integrity at $75 \mu \mathrm{g} / \mathrm{ml}(109.0 \pm 4.3 \%)$ followed by a decline at $300 \mu \mathrm{g} / \mathrm{ml}(89.4 \pm 2.3 \%)$. In case of Levisticum officinale and Calendula officinalis L. was observed significant decrease at $150 \mu \mathrm{g} / \mathrm{ml}(88.8 \pm 11.66 \%, 87.4 \pm 6.0 \%)$ and $300 \mu \mathrm{g} / \mathrm{ml} \quad(86.2 \pm 9.3 \%, 84.1 \pm 4.6 \%)$. Furthermore, Apium graveolens L. significantly increased the progesterone and testosterone production (75 and $150 \mu \mathrm{g} / \mathrm{ml}$ ) however, Levisticum officinale and Calendula officinalis $\mathrm{L}$. significantly reduced steroid hormones synthesis at 150 and $300 \mu \mathrm{g} / \mathrm{ml}$. Finally, the disturbance of GJIC was significantly affected at $300 \mu \mathrm{g} / \mathrm{ml}$ of Levisticum officinale $(82.5 \pm 7.7 \%)$ and Calendula officinalis L. (79.8 $\pm 7.0 \%)$. The balanced concentration ratio may support the Leydig cell function, steroidogenesis as well as all essential parameters that may significantly improve reproductive functions.

\section{Key words}

Leydig cells • Viability • Membrane integrity • Steroidogenesis • GJIC

\section{Corresponding author}

Tomas Jambor, BioFood centre, Faculty of Biotechnology and Food Sciences, Slovak University of Agriculture in Nitra, Tr. A. Hlinku 2, 94976 Nitra, Slovak Republic. E-mail: tomasjambor1@gmail.com

\section{Introduction}

Reproduction is an essential part of our common life, and the factors affecting it have always been a focus of extensive and continuous research. Nowadays, we recognize plenty of exogenous factors, which may interact with human and wildlife reproductive health, including heavy metals, endocrine disruptors, and other xenobiotics (Sedeh et al. 2012, Jambor et al. 2019). The majority of their negative effects, such as decreased testis 
weights, prostate cancer, poor semen quality, and insufficient production of steroid hormones, are frequently linked to damage of essential cellular organelles or disruptions to the processes responsible for normal reproductive functions (Smith 2007). In general, most of the mentioned problems could be solved by standard medical methods, especially surgical procedures, hormone therapy, or assisted reproductive technology methods. Inversely, an alternative therapy mediated by medicinal herbs may be another effective way to protect the reproductive system. Several studies have confirmed the higher compatibility of these plants with the human body and weak side effects in comparison to chemical drugs (Kooti et al. 2016). The most beneficial effect of medicinal herbs is related to the content of biologically active substances that are able to improve spermatogenesis, steroidogenesis, increase sperm count and motility, and in some cases, reverse the overall subfertility. However, properly balanced doses determine the potential effects of individual herbs. In many cases, the significant positive and protective effect was confirmed in the lower doses of medicinal plants, while the higher doses and long-term exposition could be hazardous for normal reproductive functions in males (Liu et al. 2004, Nantia et al. 2009).

Apium graveolens L. (Apiaceae) is one of the most confronted herbs with a high level of bioactive components such as limonene, sedanolide, alpha-pinene, or coumarin. Apium has a broad spectrum of effects such as anti-cancer, anti-microbial anti-inflammatory, and analgesic (Subhadradevi et al. 2011). Levisticum officinale from the same family as Araveolens $L$. contains a variety of bioactive molecules, and many previous studies confirmed anti-cancer, anti-bacterial, or spasmolytic effects. Extracts from Levisticum are also commonly used to treat rheumatism and urethritis (Ekiert 2000). Calendula officinalis L. (Asteraceae) is mainly known for its antitumor activity and cytotoxic effects on tumor cell lines. Besides, flowers from Calendula are traditionally used for their anti-inflammatory and antioxidant properties. They are also rich in pharmacologically active components, including coumarins, quercetin, beta-amyrin or narcissin (Preethi et al. 2010). Lower experimental concentrations of all plants mentioned above have been reported to have a significant impact on libido, spermatozoa quality, sexual hormone production or testis weight, and pituitarygonadal axis (Halo et al. 2019, Saha et al. 2019, Tvrdá et al. 2019, Jambor et al. 2020). Nevertheless, current knowledge about the consequences of their higher concentrations on the reproductive functions is poor and extremely limited. Simultaneously, specific molecular mechanisms of action by which medicinal plants could modulate the reproductive processes and parameters are not sufficiently understood.

There is significant evidence that gap junctional intercellular communication (GJIC) is essential for normal reproductive development. GJIC is made up of transmembrane proteins called connexins $(\mathrm{Cx})$ and, they considered as major molecular regulators of male fertility. Namely, the most abundant expressed gap junction protein connexin $43(\mathrm{Cx} 43)$ it necessary for spermatogenesis, steroidogenesis and healthy reproductive functions. Thus, testicular GJIC dysregulation caused by different stressors could affect the etiopathology of subfertility correlated with various reproductive abnormalities (Gilleron, 2015). Undoubtedly, there is a critical need to elucidate cellular interactions and clearly define effective doses of medicinal herbs for the reproductive system's proper functioning (Abbas 2017).

The present in vitro study aims to investigate the impact of ethanolic extract from Apium graveolens L., Levisticum officinale, and Calendula officinalis L. on mice TM3 Leydig cells during $24 \mathrm{~h}$ cultivation. The experiments had in view to determine whether the use of the selected medicinal herbs of known composition exhibits any positive or negative effects on the mitochondrial activity or membrane integrity, sexual hormones release, as well as intercellular communication in mice Leydig cells.

\section{Material and Methods}

\section{Preparation of the herbal extracts}

The leaves from Apium graveolens L., Levisticum officinale, and flowers from Calendula officinalis $L$. were collected at the local university's field in Nitra (Slovak Republic). Plant material was dried in the shade, mechanically comminuted, weighed, and subsequently extracted with $96 \%$ ethanol (CentralChem, Bratislava, Slovak republic) for 2 weeks. After that, the ethanol was evaporated (Stuart RE300DB rotary evaporator, Bibby Scientific Limited, United Kingdom and vacuum pump KNF N838.1.2KT.45.18) under reduced pressure $(0.5 \mathrm{bar} / \mathrm{g})$ and elevated temperature $40{ }^{\circ} \mathrm{C}$ in order to remove any residual ethanol. The crude extract was dissolved in a standard organic solvent 
dimethylsulfoxide (DMSO, Sigma-Aldrich, St. Louis, USA) and adjusted to $100 \mathrm{mg} / \mathrm{ml}$ as a starting solution (Tvrdá et al. 2016).

\section{HPLC-DAD analysis of phenolic compounds}

In the case of quantitative analysis of the phenolic compounds, the aliquots of plant materials were subjected to the high-performance liquid chromatography (HPLC-DAD). One $\mathrm{g}$ of lyophilized leaves and flowers were dissolved in methanol $(10 \mathrm{ml}, 80 \%$, Sigma-Aldrich, St. Louis, USA). Afterward, the mixture was shaken on a horizontal shaker $\left(25^{\circ} \mathrm{C}\right.$, during $8 \mathrm{~h}$, at $\left.250 \mathrm{rpm}\right)$ and filtered through $84 \mathrm{~g} / \mathrm{m}^{2}$ filter paper (Munktell, Germany). The samples were subsequently extracted in $20 \mathrm{ml}$ of $80 \%(\mathrm{v} / \mathrm{v})$ methanol by shaking horizontally (Unimax 2010, Heidolph Instrument, GmbH, Germany). The high-performance liquid chromatograph (Agilent 1260 Infinity HPLC Technologies, Waldbronn, Germany) with quaternary solvent manager coupled with degasser, sampler manager, Diode Array Detector, and column manager were used to analyse phenolic content in the harvested leaves of Apium graveolens L., Levisticum officinale and from flowers of Calendula officinalis L. HPLC measurements were performed on a Purosphere reverse phase C18 column (Darmstadt, Germany). The mobile phase consisted of acetonitrile and $0.1 \%$ phosphoric acid in double-deionized water $\left(\mathrm{ddH}_{2} \mathrm{O}\right)$. The gradient elution was as follows: $0-1 \mathrm{~min}$ isocratic elution $(90 \% \mathrm{C}$ and $10 \% \mathrm{D}), 1-6$ min linear gradient elution $(85 \% \mathrm{C}$ and $15 \% \mathrm{D}), 6-12 \min (80 \% \mathrm{C}$ and $20 \% \mathrm{D})$, $12-20 \min (30 \% \mathrm{C}$ and $70 \% \mathrm{D})$ and $20-25 \min (30 \% \mathrm{C}$ and $70 \% \mathrm{D}$ ). The column thermostat was heated up to $30{ }^{\circ} \mathrm{C}$, while the samples were kept at $6{ }^{\circ} \mathrm{C}$ in the sampler manager. The collected data were processed using the Agilent OpenLab ChemStation software for LC 3D Systems (Lukšič et al. 2016).

\section{TM3 Leydig cell culture}

The TM3 mouse Leydig cell line derived from the testis strain $\mathrm{BALB} / \mathrm{c} \mathrm{nu} /+$ was obtained from the American Type Culture Collection (ATCC, CRL-1714, Manassas, USA). As a non-tumorigenic line, TM3 Leydig cells are commonly used for a short-term in vitro cultivation to reflect variance in steroid hormone secretion. The cell culture medium consisted of DMEM/F12 (Dulbecco's Modified Eagle's Medium/Nutrient Mixture (Ham's) F12, Sigma-Aldrich, St. Louis, USA) supplemented with $5 \%$ HS (horse serum, Gibco-Life Technologies, New Zealand), $2.5 \%$
FBS (fetal bovine serum, BiochromAG, Berlin, Germany) together with $2.5 \mathrm{mmol}^{-1} \mathrm{~L}$-glutamine (SigmaAldrich, St. Louis, USA) and $1 \%$ penicillin/streptomycin solution (Sigma-Aldrich, St. Louis, USA). Leydig cells were cultured at $37{ }^{\circ} \mathrm{C}$ with $5 \% \mathrm{CO}_{2}$ and $95 \%$ saturated atmospheric humidity. Cells were regularly screened for contamination. The Leydig cells density was determined using automated cell counter TC $20^{\mathrm{TM}}$ (Bio-Rad Laboratories, California, USA) and adjust with culture medium to a final concentration of $4 \times 10^{3}$ cells per well. The cells were grown in a 96-well plate followed by precultivation of the cells for $24 \mathrm{~h}$ until a monolayer was formed. Afterward, the medium was replaced to include varying concentrations of experimental extracts Apium graveolens L., Levisticum officinale, and Calendula officinalis $\mathrm{L}$. at $37.5,75,150$ and $300 \mu \mathrm{g} / \mathrm{ml}$. All treated groups were compared to the non-treated (control) Leydig cells cultured in cell-culture media. The applied concentration range was selected according to the results of our pilot range-finding experiments. The TM3 Leydig cells remained in culture for $24 \mathrm{~h}$. The time of exposition has been chosen regarding to previous pilot study with bovine spermatozoa (Benko et al. 2019, Tvrdá et al. 2019). After the set time, cell viability, cell membrane integrity, steroid hormone production, and intercellular communication were evaluated.

\section{Cell viability assay (alamarBlue)}

To determine the effect of experimental concentrations $(37.5-300 \mu \mathrm{g} / \mathrm{ml})$ of the herbal extracts on the TM3 Leydig cell viability after $24 \mathrm{~h}$ exposure, alamarBlue $^{\mathrm{TM}}$ assay was exploited. AlamarBlue ${ }^{\mathrm{TM}}$ cell viability reagent $(\mathrm{AB}$, ThermoFisher Scientific, Invitrogen, Vantaa, Finland) is a sensitive oxidationreduction indicator that fluoresces and changes the blue colour of resazurin to a pink reduced form - resorufin upon reduction by living cells mediated by mitochondrial enzymes (Hamid et al. 2004). Following respective exposure, the culture medium was removed, the treated cells were washed with PBS (phosphate-buffer saline, $7.2 \mathrm{pH}$ ) and cultured with serum-free DMEM/F12 containing $5 \%(\mathrm{v} / \mathrm{v})$ alamarBlue solution at $37{ }^{\circ} \mathrm{C}$ under a humidified atmosphere of $95 \%$ air and $5 \% \mathrm{CO}_{2}$. After $30 \mathrm{~min}$ incubation, the fluorescence was measured at $530 \mathrm{~nm}$ against $590 \quad \mathrm{~nm} \quad$ (excitation/emission) wavelengths by a microplate reader (GloMax ${ }^{\circledR}-\mathrm{Multi}^{+}$, Promega Corporation, Madison, USA). The results are expressed as a percentage of the control (non-treated) group. 
Cell membrane integrity assay (CFDA-AM)

To examine the impact of experimental concentrations $(37.5-300 \mu \mathrm{g} / \mathrm{ml})$ of the herbal extracts on TM3 cells membrane integrity after $24 \mathrm{~h}$ incubation, 5-carboxyfluorescein diacetate, acetoxymethyl ester (CFDA-AM, ThermoFisher Scientific, Invitrogen, Vantaa, Finland) was used according to the previous study (Schreer et al. 2005). In essence, culture media supplemented with herbal extracts was replaced with fresh cultured media together with $4 \mu \mathrm{M}$ CFDA-AM. Subsequently, the TM3 cells were incubated for $30 \mathrm{~min}$ in the dark at $37{ }^{\circ} \mathrm{C}$ with $5 \% \mathrm{CO}_{2}$, and $95 \%$ saturated atmospheric humidity. The concentrations of the fluorescent metabolites of CFDA-AM were measured at wavelength 485 - $530 \mathrm{~nm}$ (excitation/emission) in a microplate reader $\left(\right.$ GloMax $^{\circledR}-\mathrm{Multi}^{+}, \quad$ Promega Corporation, Madison, USA). The results are expressed as a percentage of the control (non-treated) group.

\section{Enzyme-linked immunosorbent assay (ELISA)}

To evaluate the progesterone and testosterone production, TM3 Leydig cells were incubated together with experimental concentrations $(37.5-300 \mu \mathrm{g} / \mathrm{ml})$ of the herbal extracts. After a $24 \mathrm{~h}$ in vitro cultivation period, the cell culture media was aspirated from each well and stored in Eppendorf tubes at $-80{ }^{\circ} \mathrm{C}$ until assay. To investigate the level of steroid hormone, a commercially available ELISA kits (Dialab, progesterone Cat. \#K00225 and testosterone Cat. \#K00234, Austria) was used. The ELISA assay was carried out according to the manufacturer's specifications. The optical density was measured by an ELISA microplate reader (Multiscan FC, ThermoFisher Scientific, Vantaa, Finland) at $450 \mathrm{~nm}$ wavelength. Cell culture media was collected from four independent $(n=4)$ experiments. The results are expressed as a percentage of the control (non-treated) group.

Gap junctional intercellular communication assay (GJIC)

TM3 Leydig cells were cultured for $24 \mathrm{~h}$ exposure with selected concentrations $(37.5-300 \mu \mathrm{g} / \mathrm{ml})$ of the herbal extracts. After respective treatment, the scalpel loading/dye transfer (SL/DT) method was done as published previously Upham et al. (2016) whit slight modification. A gap junction permeable tracer lucifer yellow (1 mg/ml, Sigma-Aldrich, St. Louis, USA) was added to the cells and introduced into them by three parallel cuts made by a scalpel blade. After 6 min of incubation, the cells were washed three times with CaMg-PBS and fixed with a $4 \%$ formaldehyde solution. The images were captured by fluorescent microscope DMI 6000B (Leica Microsystems, Wetzlar, Germany) with DCF 345 FX camera. The area of cells stained with lucifer yellow was evaluated using ImageJ software (Schneider et al. 2012). The results are expressed as a percentage of the control (non-treated) group.

Statistics

The obtained data were statistically analysed using GraphPad Prism 5.0 (GraphPad Software Incorporated, San Diego, California, USA). One-way analysis of variance (ANOVA) followed by Dunnett's multiple comparison test was used for statistical evaluations. Results were expressed as the mean \pm standard deviation (S.D). All experiments were repeated at least three times. Statistical differences were expressed at a significance of $P<0.05$.

\section{Results}

\section{Bioactive compounds prevalence in herbal extracts}

We identified bioactive substances based on the retention time and the UV spectra chromatogram pattern. Detected levels of all flavonoids are summarized in Table 1 and phenolic acids in Table 2. The most prevalent flavonoids in Apium graveolens L. were vitexin $(160.18 \pm 20.33 \mathrm{mg} / \mathrm{kg}) \quad$ and cynaroside $(49.57 \pm 5.45 \mathrm{mg} / \mathrm{kg})$ followed by kaempferol, diaidzein, or kaempferol. On the other hand, ferulic acid $(523.04 \pm 42.12 \mathrm{mg} / \mathrm{kg})$ and trans-p-coumaric acid (140.69 $\pm 11.32 \mathrm{mg} / \mathrm{kg}$ ) were identified as the predominant phenolic acids in the leaves of $A$. graveolens L. extract. Similarly, Levisticum officinale contained the highest amount of cynaroside $(440.35 \pm 10.21 \mathrm{mg} / \mathrm{kg})$ together with kaempferol $(44.47 \pm 5.00 \mathrm{mg} / \mathrm{kg})$ and rutin $(40.32 \pm 3.77 \mathrm{mg} / \mathrm{kg})$. The most prevalent phenolic acids were identified as chlorogenic acid (523.67土 $15.55 \mathrm{mg} / \mathrm{kg}$ ) and neo-chlorogenic acid (365.90土 $3.09 \mathrm{mg} / \mathrm{kg}$ ). From analysed flavonoids of Calendula officinalis L. rutin $(34.36 \pm 2.87 \mathrm{mg} / \mathrm{kg})$, kaempferol $(22.77 \pm 2.01 \mathrm{mg} / \mathrm{kg})$, and apigenin $(22.01 \pm 2.09 \mathrm{mg} / \mathrm{kg})$ were the most prevalent. From the phenolic acids were identified as rosmarinic acid $(207.52 \pm 17.98 \mathrm{mg} / \mathrm{kg})$ and chlorogenic acid $(196.64 \pm 12.21 \mathrm{mg} / \mathrm{kg})$.

\section{Effects of the herbal extract on cell viability}

As shown in Fig. 1, experimental concentrations of Apium graveolens L. had a concentration-dependent 
effect on the cell viability of exposed cells compared to the control $(100.0 \pm 6.7 \%)$. The results showed that $75 \mu \mathrm{g} / \mathrm{ml}(109.0 \pm 4.3 \%)$ caused a significant $(P<0.05)$ increase in mitochondrial activity followed by a significant $(P<0.01)$ decrease at the highest tested concentration $(300 \mu \mathrm{g} / \mathrm{ml}, 89.4 \pm 2.3 \%)$. On the other hand, the same experimental concentrations of Levisticum officinale and Calendula officinalis L. had no significant effect up to $75 \mu \mathrm{g} / \mathrm{ml}$ on the presented parameter. However, higher concentrations of Levisticum initiated a significant $(P<0.05, \quad P<0.01) \quad$ decline in the cell viability $(88.8 \pm 11.66 \%, 86.2 \pm 9.3 \%) \quad$ together with Calendula $(P<0.0001,87.4 \pm 6.0 \%, 84.1 \pm 4.6 \%)$ after $24 \mathrm{~h}$ cultivation comparing to the control $(100.0 \pm 9.7 \%$ and $8.8 \%$ ).

Table 1. Major flavonoids identified and quantified (mg/kg) in Apium graveolens L., Levisticum officinale and Calendula officinalis $\mathrm{L}$.

\begin{tabular}{|c|c|c|c|c|c|c|}
\hline \multirow[t]{2}{*}{ Polyphenols } & \multicolumn{2}{|c|}{ Apium graveolens $\mathbf{L}}$. & \multicolumn{2}{|c|}{ Levisticum officinale } & \multicolumn{2}{|c|}{ Calendula officinalis $\mathrm{L}$. } \\
\hline & Mean $[\mathrm{mg} / \mathrm{kg}]$ & S.D. $[\mathrm{mg} / \mathrm{kg}]$ & Mean [mg/kg] & S.D. $[\mathrm{mg} / \mathbf{k g}]$ & Mean [mg/kg] & S.D. $[\mathrm{mg} / \mathrm{kg}]$ \\
\hline Rutin & 5.98 & 0.98 & 40.32 & 3.77 & 34.36 & 2.87 \\
\hline Vitexin & 160.18 & 20.33 & - & - & 6.27 & 0.96 \\
\hline Cynaroside & 49.57 & 5.45 & 440.35 & 10.21 & 12.99 & 1.11 \\
\hline Resveratrol & 3.32 & 0.76 & - & - & 13.80 & 1.24 \\
\hline Apigenin & 7.00 & 1.02 & 33.43 & 3.19 & 22.01 & 2.09 \\
\hline Kaempferol & 7.88 & 1.14 & 44.47 & 5.00 & 22.77 & 2.01 \\
\hline Quercetin & 4.95 & 0.78 & - & - & 17.42 & 1.55 \\
\hline Diaidzein & 7.45 & 1.02 & - & - & 14.71 & 1.72 \\
\hline Catechin & - & - & - & - & 12.22 & 0.98 \\
\hline Myricetin & - & - & - & - & 11.16 & 1.02 \\
\hline
\end{tabular}

S.D. - standard deviation

Table 2. Major phenolic acids identified and quantified $(\mathrm{mg} / \mathrm{kg})$ in Apium graveolens L., Levisticum officinale and Calendula officinalis $\mathrm{L}$.

\begin{tabular}{|c|c|c|c|c|c|c|}
\hline \multirow[t]{2}{*}{ Phenolic acids } & \multicolumn{2}{|c|}{ Apium graveolens L. } & \multicolumn{2}{|c|}{ Levisticum officinale } & \multicolumn{2}{|c|}{ Calendula officinalis $\mathrm{L}$. } \\
\hline & $\begin{array}{c}\text { Mean } \\
{[\mathrm{mg} / \mathrm{kg}]}\end{array}$ & $\begin{array}{c}\text { S.D. } \\
{[\mathrm{mg} / \mathrm{kg}]}\end{array}$ & $\begin{array}{c}\text { Mean } \\
{[\mathrm{mg} / \mathrm{kg}]}\end{array}$ & $\begin{array}{c}\text { S.D. } \\
{[\mathrm{mg} / \mathrm{kg}]}\end{array}$ & $\begin{array}{c}\text { Mean } \\
{[\mathrm{mg} / \mathrm{kg}]}\end{array}$ & $\begin{array}{c}\text { S.D. } \\
{[\mathrm{mg} / \mathrm{kg}]}\end{array}$ \\
\hline Neo-chlorogenic acid & 8.79 & 1.54 & 365.90 & 3.09 & 36.55 & 2.55 \\
\hline Protocatechuic acid & 130.78 & 12.78 & & & - & - \\
\hline $\begin{array}{l}\text { trans-p-Coumaric } \\
\text { acid }\end{array}$ & 140.69 & 11.32 & 10.99 & 1.08 & 7.36 & 0.99 \\
\hline Sinapinic acid & - & - & 5.30 & 1.04 & 55.30 & 4.01 \\
\hline trans-Sinapic acid & 21.99 & 2.05 & & & 56.32 & 4.44 \\
\hline Ferulic acid & 523.04 & 42.12 & 88.61 & 6.55 & 18.01 & 2.01 \\
\hline trans-ferulic acid & - & - & 19.02 & 2.99 & 5.94 & 0.67 \\
\hline Rosmarinic acid & 90.89 & 7.86 & & & 207.52 & 17.98 \\
\hline Chlorogenic acid & 17.39 & 1.12 & 523.67 & 15.55 & 196.64 & 12.21 \\
\hline p-Coumaric acid & 22.76 & 1.77 & & & - & - \\
\hline Caffeic acid & - & - & 55.65 & 4.01 & 28.88 & 3.09 \\
\hline trans-Caffeic acid & - & - & 22.33 & 2.69 & 57.97 & 3.63 \\
\hline Cinnamic acid & - & - & & & 21.99 & 2.88 \\
\hline Gallic acid & - & - & & & 6.99 & 0.78 \\
\hline
\end{tabular}

S.D. - standard deviation 


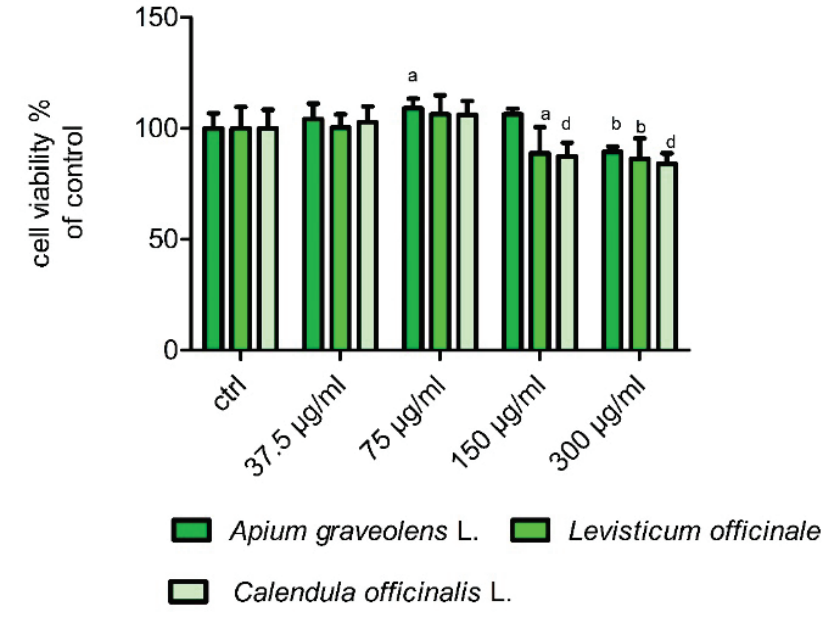

Fig. 1. The effects of Apium graveolens L., Levisticum officinale and Calendula officinalis L. on TM3 Leydig cell viability in vitro after $24 \mathrm{~h}$ cultivation. ctrl - control group. Each bar represents the mean $( \pm$ S.D) viability \% of control (untreated) and treated groups. Data were obtained from four $(n=4)$ independent experiments. The level of significance was set at $(P<0.05)$. Statistical differences between the values of control and experimental groups are indicated as: a - Significant difference from the control $\mathrm{P}<0.05, \mathrm{~b}$-Significant difference from the control $\mathrm{P}<0.01, \mathrm{~d}-$ Significant difference from the control $\mathrm{P}<0.0001$.

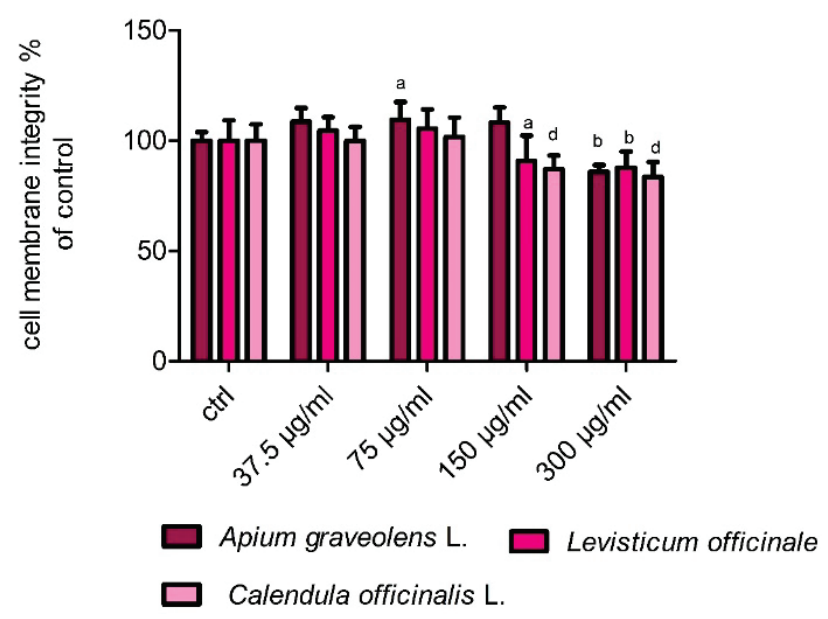

Fig. 2. The effects of Apium graveolens L., Levisticum officinale and Calendula officinalis L. on TM3 Leydig cell membrane integrity in vitro after $24 \mathrm{~h}$ cultivation. ctrl - control group. Each bar represents the mean ( \pm S.D) cell membrane integrity \% of control (untreated) and treated groups. Data were obtained from four $(n=4)$ independent experiments. The level of significance was set at $(P<0.05)$. Statistical differences between the values of control and experimental groups are indicated as: a - Significant difference from the control $\mathrm{P}<0.05, \mathrm{~b}$ - Significant difference from the control $\mathrm{P}<0.01, \mathrm{~d}$ - Significant difference from the control $\mathrm{P}<0.0001$.

\section{Effect of the herbal extract on cell membrane integrity}

The results present in Fig. 2. have revealed that almost all applied concentrations of Apium graveolens L. positively affect this parameter with significant $(P<0.05)$ impact at $75 \mu \mathrm{g} / \mathrm{ml}(109.6 \pm 7.9 \%)$. Significant reduction
$(P<0.01)$ was recorded at $300 \mu \mathrm{g} / \mathrm{ml}(85.9 \pm 2.9 \%)$. In respect to remaining extracts, $150 \mu \mathrm{g} / \mathrm{ml}(88.8 \pm 11.6 \%)$ and $300 \mu \mathrm{g} / \mathrm{ml}(86.2 \pm 9.3 \%)$ of Levisticum officinale significantly $(P<0.05, \quad P<0.01)$ reduced presented parameters. In addition, a significant $(P<0.0001)$ cytotoxic effect was confirmed at the same concentrations of Calendula officinalis L. Reduced cell membrane integrity fluctuated between $87 \%( \pm 6.2 \%)$ and $84 \%$ $( \pm 6.8 \%)$. Experimental groups were compared to the control $(100.0 \pm 3.9 \%, 9.2$ and $7.4 \%)$.

\section{Effect of the herbal extract on hormone production}

As seen in Fig. 3A applied doses (75 and $150 \mu \mathrm{g} / \mathrm{ml}$ ) of Apium significantly enhanced progesterone production ( $116.0 \pm 3.1 \%$ and $114.4 \pm 8.5 \%$ ) followed by decline at $300 \mu \mathrm{g} / \mathrm{ml}$. On the other hand, higher experimental concentrations of Levisticum decreased progesterone release at $300 \mu \mathrm{g} / \mathrm{ml}(90.9 \pm 8.5 \%)$, while the same dose of Calendula reduced steroid production significantly $(86.1 \pm 7.5 \%)$. All experimental groups were compared to the control group $(100.0 \pm 4.9 \%, 6.7 \%$ and $1.6 \%$ ). Fig. $3 \mathrm{~B}$ indicated the strongest stimulating potential of Apium graveolens L. with a significant increase at $150 \mu \mathrm{g} / \mathrm{ml}(114.4 \pm 2.1 \%)$, while the highest concentration $(300 \mu \mathrm{g} / \mathrm{ml})$ caused a non-significant decline. Overleaf, a weak stimulating effect was observed after Levisticum and Calendula treatment. Higher concentrations (150 and $300 \mu \mathrm{g} / \mathrm{ml}$ ) initiate a gradual decline in testosterone production, but only Calendula caused a significant decrease $(P<0.05, P<0.001)$. The level of testosterone was defined at $87.9 \pm 4.9 \%$ and $77.5 \pm 6.8 \%$ comparing to the control $(100.0 \pm 3.2 \%$ and $4.9 \%)$.

Effect of the herbal extract on intercellular communication

As seen in Fig. 4A, exposure to none of the treatments by Apium (37.5-300 $\mu \mathrm{g} / \mathrm{ml})$ caused significant changes in intercellular communication. Overleaf, this biomarker was significantly $(P<0.05)$ inhibited at 300 $\mu \mathrm{g} / \mathrm{ml}$ of Levisticum officinale $(82.5 \pm 7.7 \%)$ and Calendula officinalis L. (79.8 $\pm 7.0 \%)$. All treated groups were compared to the control group $(100.0 \pm 4.6 \%$, $4.6 \%$ and $4.4 \%$ ). The representative images of GJIC activity are shown in Fig. 4B.

\section{Discussion}

Numerous studies have shown that medicinalherbs, which are a rich source of different 


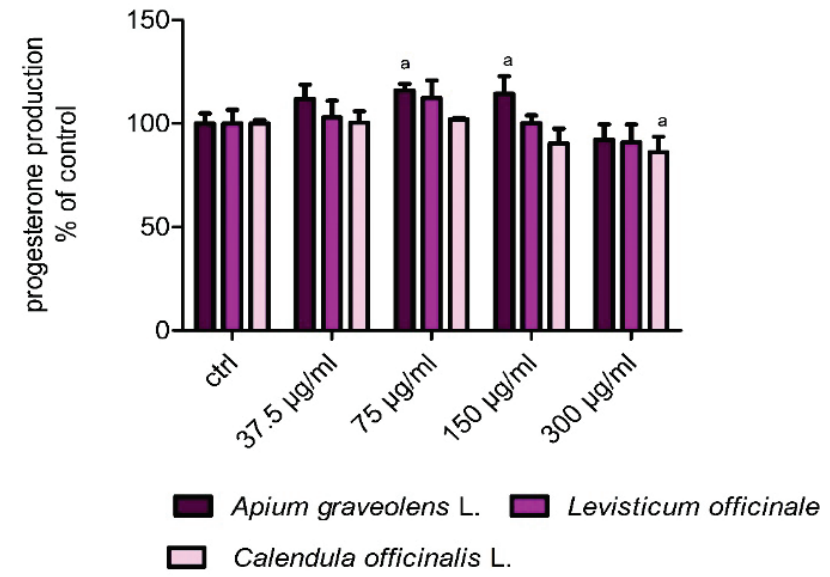

Fig. 3.A Progesterone production in TM3 Leydig cells exposed to different concentrations of experimental extracts from Apium graveolens L., Levisticum officinale and Calendula officinalis L. in vitro after $24 \mathrm{~h}$ cultivation. ctrl - control group. Each bar represents the mean ( $\pm S . D$ ) progesterone production \% of control (untreated) and treated groups. Data were obtained from four $(n=4)$ independent experiments. The level of significance was set at $(P<0.05)$. Statistical differences between the values of control and experimental groups are indicated as: a - Significant difference from the control $\mathrm{P}<0.05$.

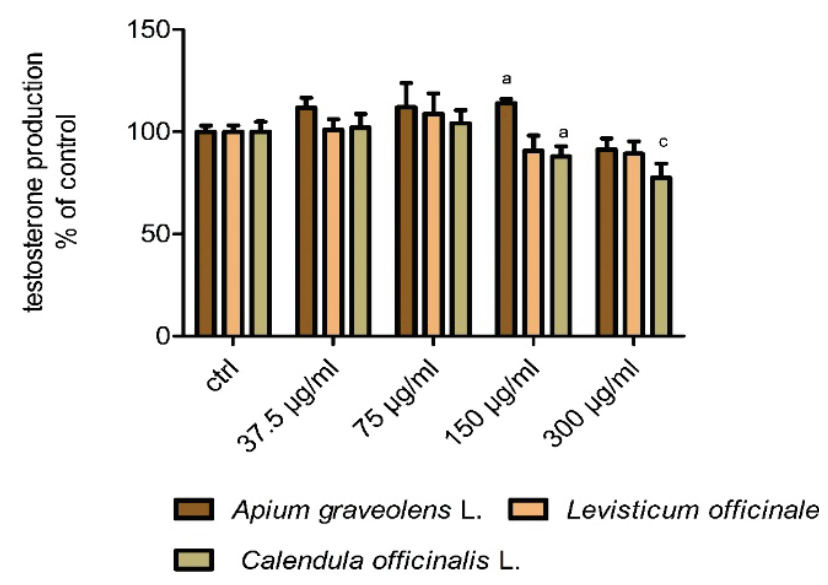

Fig. 3.B Testosterone production in TM3 Leydig cells exposed to different concentrations of experimental extracts from Apium graveolens $\mathrm{L} .$, Levisticum officinale and Calendula officinalis $\mathrm{L}$. in vitro after $24 \mathrm{~h}$ cultivation. ctrl - control group. Each bar represents the mean ( \pm S.D) testosterone production \% of control (untreated) and treated groups. Data were obtained from four $(n=4)$ independent experiments. The level of significance was set at $(P<0.05)$. Statistical differences between the values of control and experimental groups are indicated as: a - Significant difference from the control $\mathrm{P}<0.05, \mathrm{c}$ - Significant difference from the control $\mathrm{P}<0.001$.

phytoconstituents, could be associated with many health benefits. Bioactive compounds appear to play an important protective role in cardiovascular diseases, hepatic diseases, reproductive problems, the onset of cancer, and other chronic pathologies (Nour et al. 2017). The results of our in vitro study indicate a significant

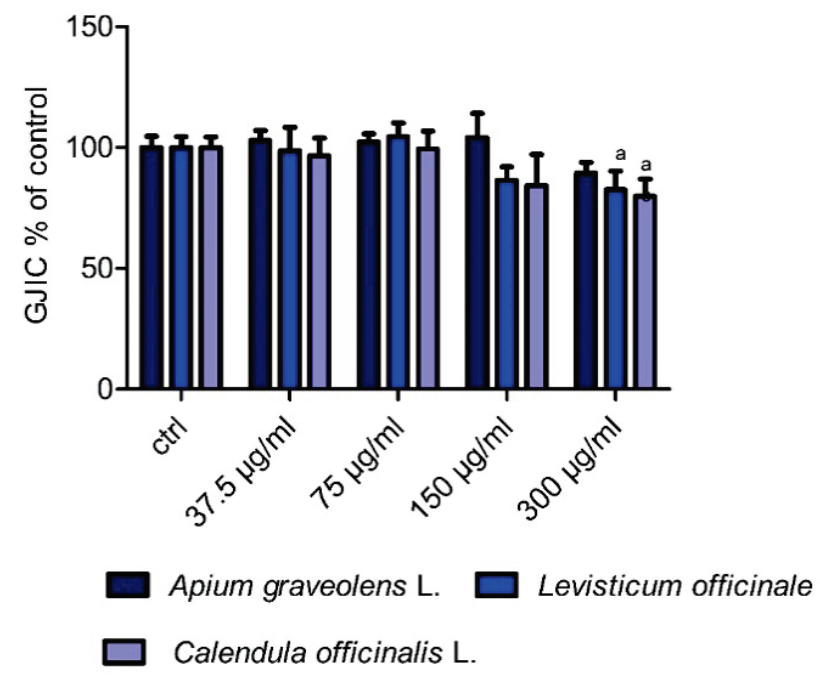

Fig. 4.A Intercellular communication in TM3 Leydig cells exposed to different concentrations of experimental extracts from Apium graveolens L., Levisticum officinale and Calendula officinalis $L$. in vitro after $24 \mathrm{~h}$ cultivation. ctrl - control group. Each bar represents the mean ( \pm S.D) GJIC \% of control (untreated) and treated groups. Data were obtained from three $(n=3)$ independent experiments. The level of significance was set at $(P<0.05)$. Statistical differences between the values of control and experimental groups are indicated as: a - Significant difference from the control $\mathrm{P}<0.05$.

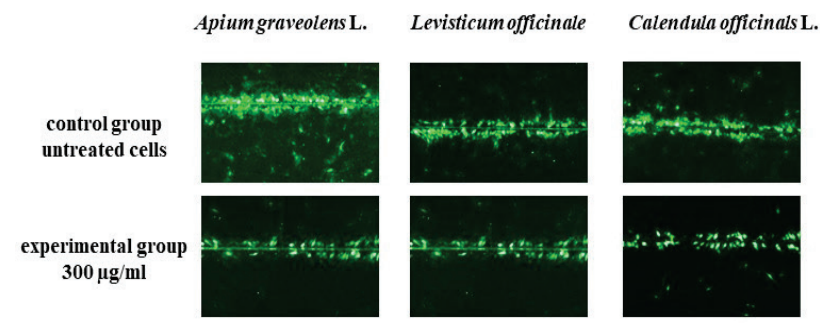

Fig. 4.B The representative images of GJIC activity in the control group, and after $24 \mathrm{~h}$ exposure to $300 \mu \mathrm{g} / \mathrm{ml}$ of Apium, Levisticum and Calendula followed by SL/DT technique. The lucifer yellow dye spreading into the Leydig TM3 cells is related to the GJIC extent

dose-dependent effect of medicinal herbs extracts on TM3 Leydig cells. Lower applied doses of positively affect selected cellular parameters, while the highest concentrations $(150$ and $300 \mu \mathrm{g} / \mathrm{ml})$ of Calendula and Levisticum progressively reduced cell viability and cell membrane integrity, decreased progesterone, and testosterone secretion as well as inhibited intercellular communication.

The quantitative evalu ation of experimental extract performed by HPLC-DAD analysis confirmed a wide range and variegated ratio of polyphenols and phenolic acids (Table 1 and 2). Many of them are capable to positively affect the reproductive functions in males. 
A high proportion of bioactive molecules was confirmed by Yao et al. (2010). Their study identified major phenolic acids in different cultivars of Apium graveolens such as p-coumaric acid $(105 \mathrm{mg} / \mathrm{kg})$ ferulic acid $(99.3 \mathrm{mg} / \mathrm{kg})$, followed by flavonoids apigenin $(92.1 \mathrm{mg} / \mathrm{kg})$, luteolin $(90.5 \mathrm{mg} / \mathrm{kg})$ or kaempferol $(94.6 \mathrm{mg} / \mathrm{kg})$. Similar to our results, Złotek et al. (2019) identified ferulic acid, ellagic acids, p-coumaric acid, caffeic acid, kaempferol, rutin, apterin, and quercetin-3O-deoxhexoside-O-hexodside as the most abundant in Levisticum officinale L. Frum (2017) has monitored the level of polyphenols in Calendula officinalis L. where the highest concentrations of rutin, syringic acid, and gallic acid were recorded. The lower amounts of cinnamic acid, resveratrol, and ferulic acid were also detected. All presented studies above confirmed similar levels of bioactive substances in our experimental medicinal herbs. We are convinced that their detailed identification and monitoring is definitely required for a better understanding of the physiological mechanism as well as to help understand the potential changes in the male reproductive system.

Mutual comparison of individual cellular models confirmed different reactions to presented medicinal herbs extracts. The vast majority of in vitro studies are focused on tumorogenic cell lines where the increasing concentrations of herbal extract inhibit cancer proliferation. In contrast, the result of our in vitro study confirmed that lower experimental concentrations might positively affect essential parameters of non-tumorigenic cells, especially the cell viability and cell membrane integrity, but with increasing doses start at 150 to $300 \mu \mathrm{g} / \mathrm{ml}$ are able to significantly damage these parameters. Comparable consequences have previously been reported by Subhadradevi et al. (2011). Mouse lung fibroblast L929 cells were exposed to Apium graveolens at concentrations ranging from 2 to $20 \mu \mathrm{g} / \mathrm{ml}$ during $48 \mathrm{~h}$ and the number of viable cells was determined by the MTT assay. The herbal extract statistically inhibited this parameter in a concentration-dependent manner. Sertel et al. (2011) evaluated the impact of Levisticum officinale extract on the head and neck squamous carcinoma cells (HNSCC) using XTT cytotoxicity assay. The biological model was cultured together with experimental concentrations $(0.0001$ to $10 \mathrm{mg} / \mathrm{ml})$ of extract for $72 \mathrm{~h}$ in vitro. The concentration-response curve showed a steady rise in the viability up to $0.1 \mathrm{mg} / \mathrm{ml}$ with a subsequent rapid decrease in cell viability to $4.7 \%$ ( 1 and $10 \mathrm{mg} / \mathrm{ml}$ ) when compared to the untreated control cells. The beneficial effects of Calendula officinalis L. were confirmed by many experimental studies focused on cancer diseases in most cases. However, only a few studies provide information about the cytotoxic concentrations in non-carcinoma cells. Alnuqaydan et al. (2015) measured the cytotoxicity of the extract from $C$. officinalis $L$. at di fferent concentrations for 4,24 , and $48 \mathrm{~h}$ on $\mathrm{HaCaT}$ cells in vitro. Calendula showed limited toxicity with a significant effect in the highest concentration. Only 4.4 and $4.2 \mathrm{mg} / \mathrm{ml}$ expressed as $2 \%$ $(\mathrm{v} / \mathrm{v})$ and $5 \%(\mathrm{v} / \mathrm{v})$ showed a significant toxicity. The viability of HUVEC cells was monitored after $48 \mathrm{~h}$ in vitro cultivation with $C$. officinalis $\mathrm{L}$. $(0.5-500 \mu \mathrm{g} / \mathrm{ml})$ by MTT assay. The results suggest a gradual decline up to $10 \mu \mathrm{g} / \mathrm{ml}$, followed by a radical cytotoxic effect at 250 and $500 \mu \mathrm{g} / \mathrm{ml}$ (Preethi et al. 2010). According to the current knowledge, extract from selected medicinal herbs used in our study could protect sensitive cellular organelles and cell homeostasis in a concentrationdependent manner. It is caused by the mutual ratio of bioactive molecules whose high levels have been confirmed by the previous part of our analysis. Obtained results suggest that some experimental concentrations may negatively affect basal cellular parameters what could result from higher toxic potential of selected extracts. Furthermore, we can assume that the cellular membrane destruction or cell death could destroy steroidogenesis enzymes activity resulting in decreased hormone production. To resolve this issue, further investigations are required. At the same time, we are convinced that adequately applied dose settings could improve males' reproductive functions. The cell structure and mitochondrial activity are closely related to the steroidogenic process ongoing in Leydig cells responsible for steroid hormone production.

Our in vitro study's data suggest that the secretion of progesterone and testosterone could be positively affected by the lower doses ( 75 and $150 \mu \mathrm{g} / \mathrm{ml}$ ) of Apium graveolens L. However, at the highest concentration of Apium graveolens L., Levisticum officinale, and Calendula officinalis L. has recorded a significant decrease in steroidogenic capacity resulting in a decline of progesterone and testosterone levels. The efficacy of hydro-alcoholic extracts of A. graveolens L. on the serum levels of testosterone in male rats was investigated by Kooti et al. (2016). Male Wistar rats were orally administered to 200 and $300 \mathrm{mg} / \mathrm{kg}$ of A. graveolens L. for 20 days. The results showed a slight decrease in testosterone production at $300 \mathrm{mg} / \mathrm{kg}$, but 
without significant changes. Similarly, Madkour (2014) administered orally male albino rats at $200 \mathrm{mg} / \mathrm{kg}$ per day of A. graveolens L. oil for 8 weeks. The radioimmunoassay revealed an increased concentration of testosterone when compared to the control group. Interestingly, Helal (2014) confirmed a slight decrease in testosterone secretion in male Wistar rats after 6 weeks of exposure to $50 \mu \mathrm{g} / \mathrm{kg}$ per body weight of $A$. graveolens $\mathrm{L}$. Ghaedi et al. (2018) published an experimental study focused on the effect of Levisticum officinale extract on the testis histology and testosterone production in diabetic rats. Treatment of rats with $500 \mathrm{mg} / \mathrm{kg}$ significantly increased the testis weight and serum testosterone levels. The authors assumed that effective concentrations might reduce testicular tissue destructions. The effect of Calendula on the male reproductive functions of rats was evaluated by Kushwaha et al. (2007). Healthy male albino rats were orally administrated $200 \mathrm{mg} / \mathrm{kg}$ body weight of an extract from C. officinalis for 60 days. The results confirmed a significant decrease in sperm motility and density as well as a significant reduction in serum testosterone level.

Gap junctional intercellular communication control testis functions at multiple steps such as testis development, steroid hormone production or spermatogenesis. At the same time, GJIC is extremely sensitive to exogenous stressors, and in many cases could partly participate in subfertility. Similarly, to our results Gao et al. (2014) evaluated the effect of Apium graveolens L. seed extract on expression of gap junctional protein in human stomach cancer cell line Hs746T in vitro. Semi-quantitative RT-PCR, and Western blot analysis revealed an increase in endogenous Cx43 mRNA and protein expression following by Apium treatment, especially at $100 \mu \mathrm{g} / \mathrm{ml}$ after $72 \mathrm{~h}$. Nakamura et al. (2005) evaluated the effect of kaempferol, as an important molecule of Calendula and Levisticum on GJIC of MSU-2 human foreskin fibroblasts (HCT116) and human colon cancer cells (KNC). GJIC was measured 7 days after addition of experimental doses (5 and $10 \mu \mathrm{M}$ ). Kaempferol was found to enhance the level of GJIC in KNC cells to 1.33 times $(5 \mu \mathrm{M})$ and 1.29 times $(10 \mu \mathrm{M})$ higher than control- untreated cells. On the other hand, no enhancement of GJIC was detected in HCT116 cells following kaempferol treatment.

We are convinced, that dysregulation of GJIC presented in our study could be an essential part of the toxic mechanism related to the action of experimental extracts. According to presenting data, the TM3 mice Leydig cells are susceptible to the highest doses of applied medicinal herbs extracts with a toxic impact on essential cellular organelles and functions. However, as we mentioned before, the exact determination of proper concentrations may definitely affect the activity of mice Leydig cells and ensure sufficient production of male steroid hormones. Nowadays, the majority of experimental studies provide a broad spectrum of information, which is not consistent. Therefore, systematic and detailed research is definitely required for an exact conclusion formulation.

\section{Conclusion}

Presented data revealed significant concentration-dependent effects of Apium graveolens L. Levisticum officinale and Calendula officinalis L. on cell viability, membrane integrity, steroidogenesis, and intercellular communication of TM3 Leydig cells after short time cultivation. It has been shown that although medically used plants have a strong potential to inhibit the onset of many pathological conditions as well as support reproductive abilities, higher applied doses can encourage toxic effects mediated through reduced viability, membrane integrity as well as GJIC inhibition. Given these in vitro observations, we assume that a balanced concentration ratio may support the Leydig cell function, steroidogenesis, and all essential parameters that may significantly improve reproductive capacity in males.

\section{Conflict of Interest}

There is no conflict of interest.

\section{Acknowledgements}

This work was financially supported by the Scientific Agency of the Slovak Republic VEGA no. 1/0083/21 and Slovak Research and Development Agency Grant no. APVV-16-0289, APVV-15-0543.

\section{References}

ABBAS MA: Is the use of plants in Jordanian folk medicine for the treatment of male sexual dysfunction scientifically based? Review of in vitro and in vivo human and animal studies. Andrologia 49: 1-21, 2017. https://doi.org/10.1111/and.12619 
ALNUQAYDAN AM, LENEHAN CE, HUGHES RR, SANDERSON BJ: Extracts from Calendula officinalis offer in vitro protection agains $\mathrm{H} 2 \mathrm{O} 2$ induced oxidative stress cell killing of human skin cells. Phytother Res 29: 120-124, 2015. https://doi.org/10.1002/ptr.5236

BENKO F, PALKOVIČOVÁ V, ĎURAČKA M, ÁRVAY J, LUKÁČ N, TVRDÁ E: Antioxidant effects of marigold (Calendula officinalis) flower extract on the oxidative balance of bovine spermatozoa. Contemporary Agriculture 68: 92-102, 2019. https://doi.org/10.2478/contagri-2019-0015

EKIERT H: Medicinal plant biotechnology: the Apiaceae family as the example of rapid development. Pharmazie 55: 561-567. 2000.

FRUM A: HPLC determination of polyphenols from Calendula officinalis L. flowers. AUCFT 21: 97-101, 2017. https://doi.org/10.1515/aucft-2017-0020

GAO LL, ZHOU CHX, SONG, XF, FAN KW, LI FR: Inhibition effects of celery seed extract on human stomach cancer cell lines Hs746T. In: Frontier and Future Development of Information Technology in Medicine and Education. S Li, Q Jin, X Jiang, JJ Park. (eds), Springer, Switzerland AG, 2014, pp 2553-2560. https://doi.org/10.1007/978-94-007-7618-0 319

GHAEDI N, POURABOLI I, DABIRI S: Effect of Levisticum officinale extract on oxidative stress markers, testosterone level and histology of testis tissue in diabetic rats. Ir J Physiol Pharmacol 2: 192-200, 2018.

GILLERON J: Connexins as potential therapeutic targets for testis pathologies. Cell Mol Med 1: 1-3, 2015. https://doi.org/10.21767/2573-5365.100001

HALO JR M, MASSANYI P, GREN A, LASAK A, SLANINA T, ONDRUSKA L, MUCHACKA R, GALBAVY D, IVANIC P, SCHNEIR R, FORMICKI G: Time and dose-dependent effect of Viscum album quercus on rabbit spermatozoa motility and viability in vitro. Physiol Res 68: 955-972, 2019. https://doi.org/10.33549/physiolres.934223

HAMID R, ROTSHTEYN Y, RABADI L, PARIKH R, BULLOCK P: Comparison of alamar blue and MTT assays for high through-put screening. Toxicol In Vitro 18: 703-710, 2004. https://doi.org/10.1016/j.tiv.2004.03.012

HASAN A, SHAHRAKI A, SHAHRAKI J: The hepatoprotective effects of aquatic extract of Levisticum officinale against paraquat hepatocyte toxicity. Pak J Pharm Sci 30: 2363-2368. 2017.

HELAL MAM: Celary oil modualtes DEHP-induced treproductive toxicity in male rats. Reprod Biol 14: 182-189, 2014. https://doi.org/10.1016/j.repbio.2014.04.002

JAMBOR T, KOVACIKOVA E, GREIFOVA H, KOVACIK A, LIBOVA L, LUKAC N: Assesment of the effective impact of bishpenols on mitochondrial activity and steroidogenesis in a dose-dependency in mice TM3 Leydig cells. Physiol Res 68: 689-693, 2019. https://doi.org/10.33549/physiolres.934200

JAMBOR T, ARVAY J, IVANISOVA E, TVRDA E, KOVACIK A, GREIFOVA H, LUKAC N: Investigation of the properties and effects of Salvia Officinalis L. on the viability, steroidogenesis and reactive oxygen species production in TM3 Leydig cells in vitro. Physiol Res 69: 661-673, 2020. https://doi.org/10.33549/physiolres.934457

KOOTI W, FAROKHIPOUR M, ASADZADEH Z, ASHTARY-LARKY D, ASADI-SAMANI M: The role of medicinal plants in the treatment of diabetes: a systematic review. Electron Physician 8: 1832-1842, 2016. https://doi.org/10.19082/1832

KUSHWAHA S, AGARWAL M, MUTREJA A, CHAUHAN A: Impact of $50 \%$ ethanolic extract of Calendula officinalis (flower) on the reproductive funcion of male albino rats (Rattus norvegicus). Egypt J Biol 9: 1-5, 2007. https://doi.org/10.4314/ejb.v9i1.56552

LIU J, LIANG P, YIN C, WANG T, LI H, LI Y, YE Z: Effects of several Chinese herbal aqueous extracts on human sperm motility in vitro. Andrologia 36: 78-83, 2004. https://doi.org/10.1111/j.1439-0272.2004.00607.x

LUKŠIČ L, ÁRVAY J, VOLLMANNOVÁ A, TÓTH T, ŠKRABANJA V, TRČEK J, GERM M, KREFT I. Hydrothermal treatment of Tartary buckwheat grain hinders the transformation of rutin to quercetin. J Cer Sci 72: 131-134, 2016. https://doi.org/10.1016/j.jcs.2016.10.009.

MADKOUR NK: Beneficial role of celery oil in lowering the di(2-ethylhexyl) phtalata-induced testicular damage. Toxicol Ind Health 30: 861-872. 2014. https://doi.org/10.1177/0748233712464808 
NAKAMURA Y, CHANG CH, MORI T, SATO K, OHTSUKI K, UPHAM BL, TROSKO JE: Augmentation of differentiation of gap juncion function by kaempferol in partially differentiated colon cancer cells. Carcinogenesis 26: 665-671, 2005. https://doi.org/10.1093/carcin/bgi003

NANTIA EA, MOUNDIPA PF, MONSEES TK, CARREAU S: Medicinal plants as potential male anti-invertility agents: a review. Bas Clin Adrol 19: 148-158. 2009. https://doi.org/10.1007/s12610-009-0030-2

NOUR V, TRANDAFIR I, COSMELESCU S: Bioactive compounds, antioxidat activity and nutritional quality of different culinar aromatic herbs. Not Bot Horti Agro Cluj Nap 45: 179-184, 2017. https://doi.org/10.15835/nbha45110678

PREETHI KC, SIVEEN KS, KUTTAN R, KUTTAN G: Inhibition of metastasis of B16F-10 melanoma ce BL/6 mice and extract of calendula officinalis L flowers. Asian Pac J Cancer Prev 11: 1773-1779, 2010.

SAHA R, ROYCHODHURY S, KAR K, VARGHESE AC, NANDI P, SHARMA GD, FORMICKI G, SLAMA P, KOLESAROVA A: Coenzyme Q10 ameliorates cadmium induced reproductive toxicity in male rats. Physiol Res 68: 141-145, 2019. https://doi.org/10.33549/physiolres.934000

SEDEH MA, SIAHPOUSH EA, DARVISHZADEH Z: The investigation of fertility increase and effective factors on it among the kord clan in Andimeshk. JISDS 4: 81-98, 2012.

SERTEL S, EICHHORM T, PLINKERT PK, EFFERTH T: Chemical composition and antiproliferative activity of essential oil from the leaves of a medicinal herb, Levisticum officinale, against UMSCC1 head and neck squamous carcinoma cells. Anticancer Res 32: 185-191, 2011.

SCHNEIDER CA, RASBAND WS, ELICEIRI KW: NIH image to ImageJ: 25 years of image analysis. Nat Methods 9: 671-675, 2012. https://doi.org/10.1038/nmeth.2089

SCHREER A, TINSON CH, SHERRY JP, SCHIRMER K: Application of alamar blue/5-carboxylfluorescein diacetate acetoxymethly ester as a noninvasive cell viability assay in primary hepatocytes from rainbow trout. Anal Biochem. 344: 76-85, 2005. https://doi.org/10.1016/j.ab.2005.06.009

SMITH S: Drubs that cause sexual dysfuncion. Psychiatry 6: 111-114. 2007. https://doi.org/10.1016/j.mppsy.2006.12.004

SUBHADRADEVI V, KHAIRUNISSA K, ASOKKUMAR K, SIVASHANMUGAM MUA, JAGANNAT P: Induction of apoptosis and cytotoxic activities of Apium graveolnes Linn. using in vitro models. Mid East J Sci Res 9: 90-94, 2011.

SUN J, WANG H, LIU B, SHI W, SHI J, ZHANG Z, XING J: Rutin attenuates $\mathrm{H}_{2} \mathrm{O}_{2}$-iduced oxidation damage and apoptosis in Leydig cells by activating PI3K/Akt signal pathways. Biomed Pharm 88: 500-506, 2017. https://doi.org/10.1016/i.biopha.2017.01.066

TVRDÁ E, MICHALKO J, MATUŠÍKOVÁ I, LUKÁČ N: In vitro effects of the Chlamydomonas reinhardtii extract on bovine spermatozoa. J Microbiol Biotech Food Sci 6: 972-975, 2016. https://doi.org/10.15414/jmbfs.2016/17.6.3.972-975

TVRDÁ E, VARGA A, SLÁVIK M, ÁRVAY J: Levisticum officinale and its effects on bovine spermatozoa activity. J Microbiol Biotech Food Sci. 8: 1212-1216, 2019. https://doi.org/10.15414/jmbfs.2019.8.5.1212-1216

UPHAM BL, SOVADINOVA I, BABICA P: Gap juncional intercellualr communication: a funcional biomarker to assess adverse effects of toxicants and toxins, and health benefits of natural product. J Vis Exp 118: 54281, 2016. https://doi.org/10.3791/54281

YAO Y, SANG W, ZHOU M, REN G: Phenolic composition and antioxidant activities of 11 celery cultivars. J Food Sci 75: 9-13. 2010. https://doi.org/10.1111/j.1750-3841.2009.01392.x 